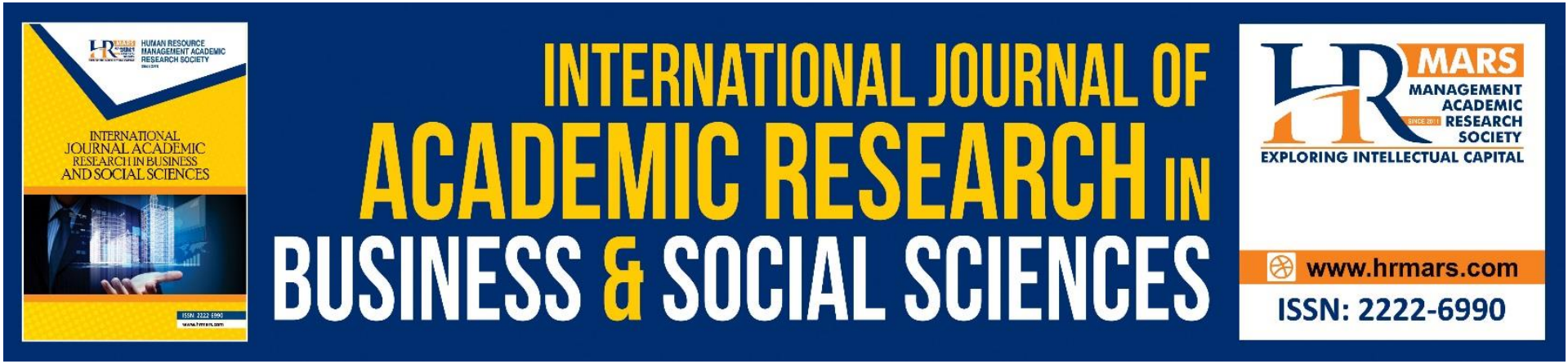

\title{
A Preliminary Finding of Organization Citizenship Behaviour and Job Satisfaction among Special Education Teachers
}

Suriani Abdul Hamid, Suzyanty Mohd Shokory, Marinah Awang, Khalip Musa

To Link this Article: http://dx.doi.org/10.6007/IJARBSS/v11-i12/11614

DOI:10.6007/IJARBSS/v11-i12/11614

Received: 09 October 2021, Revised: 13 November 2021, Accepted: 28 November 2021

Published Online: 23 December 2021

In-Text Citation: (Hamid et al., 2021)

To Cite this Article: Hamid, S. A., Shokory, S. M., Awang, M., \& Musa, K. (2021). A Preliminary Finding of Organization Citizenship Behaviour and Job Satisfaction among Special Education Teachers. International Journal of Academic Research in Business and Social Sciences, 11(12), 1891-1900.

Copyright: (c) 2021 The Author(s)

Published by Human Resource Management Academic Research Society (www.hrmars.com)

This article is published under the Creative Commons Attribution (CC BY 4.0) license. Anyone may reproduce, distribute, translate and create derivative works of this article (for both commercial and non0-commercial purposes), subject to full attribution to the original publication and authors. The full terms of this license may be seen

at: http://creativecommons.org/licences/by/4.0/legalcode

Vol. 11, No. 12, 2021, Pg. $1891-1900$

Full Terms \& Conditions of access and use can be found at http://hrmars.com/index.php/pages/detail/publication-ethics 


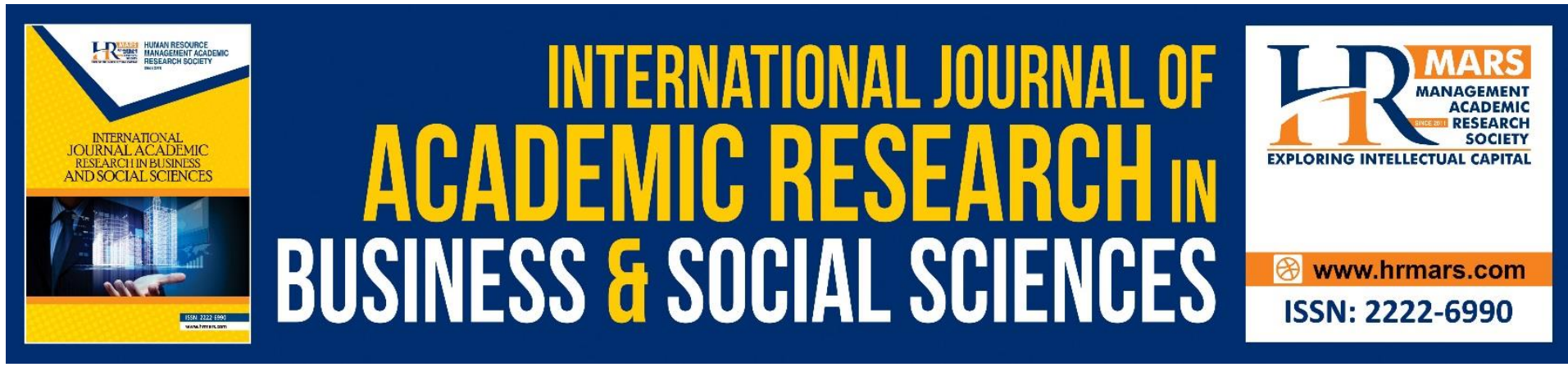

\title{
A Preliminary Finding of Organization Citizenship Behaviour and Job Satisfaction among Special Education Teachers
}

\author{
Suriani Abdul Hamid, Suzyanty Mohd Shokory, Marinah \\ Awang, Khalip Musa \\ Faculty of Management and Economics, Universiti Pendidikan Sultan Idris \\ Corresponding Author Email: suriani@fpe.upsi.edu.my
}

\begin{abstract}
This study aimed to identify organizational citizenship behaviors and job satisfaction among special education teachers. This study utilised a quantitative approach with the survey method. Questionnaires were used as an instrument to collect research data from a sample of Special Education Integration Program teachers in the state of Perak, Malaysia. Overall, the preliminary findings showed that organizational citizenship behavior and job satisfaction among special education teachers were at a high level. It was also found that there existed a positive relationship between organizational citizenship behavior and job satisfaction. Findings from this study may contribute to the existing literature as well as provide empirical evidence related to organizational citizenship behavior and job satisfaction among special education teachers. In addition, the findings of this study were also expected to provide useful information to the State Department of Education regarding the organizational citizenship behavior practiced by special education teachers and how it affected their job satisfaction. Thus, appropriate strategies could be implemented at the school level and the State Education Department so that an effective and efficient education system could be implemented.
\end{abstract}

Keywords: Organization Citizenship Behavior, Job Satisfaction, Special Education Programme, Malaysia

\section{Introduction}

Special education teachers are teachers who are responsible for teaching special children. They need to confront and deal with the plight of children with mental retardation, learning disabilities, emotional and behavioral problems, language and communication problems, physical and health problems, hearing problems, and vision problems. Among the challenges that need to be addressed by special education teachers is to ensure that these special students have self-management skills. Special education teachers also often act as counselors and become a place to students to confide in, discuss, ask for advice and assistance that goes beyond problems in the classroom (Roso, 2014). Special education students also tend to imitate every behavior shown by their teachers, so the teachers need to show good character and example. All these tasks require a high degree of patience and perseverance. This also 
shows that there is a need to understand in depth about the difficulties faced by special education teachers to obtain job satisfaction when educating special students (Mohamad \& Yaacob, 2013).

Roso (2014) found that the level of job satisfaction among special education teachers was high but this may differ based on their work experience. Meanwhile, Mohamad and Yaacob (2013) found that there was no significant differences based on remuneration factors, duties and work environment among special education teachers in primary and secondary schools. Norazmi et al (2020) found that principal leadership \& workload influenced special education teacher job satisfaction. A study by Strydom et al (2012) in South Africa found that the level of job satisfaction of special education teachers was at a moderate level. On the other hand, Yavuz (2018) found that there was a significant difference in job satisfaction of special education teachers in Turkey based on salary, support from peers and praise from school administrators.

Special education teachers are burdened not only with teaching tasks, but clinical tasks and students' self -management. The implementation of the Zero Reject Policy by the Ministry of Education Malaysia to ensure that students with special needs receive education in line with their abilities in mainstream schools via the Inclusive Education Programme (IEP), the Special Education Integrated Programme (SEIP) or the Special Education School (SES) ("KPM Tambah Guru", 2019) is one of the challenging tasks faced by these teachers. They therefore need to do more than formal responsibilities which are also known as organizational citizenship behavior practices. These practices are effective and able to increase the effectiveness of organizational functions and the ability to deal with these special students (Oplatka, 2009). However, Yılmaz and Taşdan (2009) stated that the practice of organizational citizenship behavior was still a uncommon practice. While Hairuddin (as mentioned in Ariffin, 2014) found that only $9.9 \%$ of teachers had organizational citizenship behavioral characteristics. With the involvement of more teachers in the practice of organizational citizenship behavior, it will indirectly improve the complexity and challenge of educating these students which is evident from a recent study by (Ibrahim et al., 2020)

An extensive body of research has studied organizational citizenship behaviour in education setting such Amira et al (2020); Choong et al (2016); Fatimah et al (2011); Norazmi et al (2020); Oplatka (2009); Shamsuddin et al (2020); Yilmaz and Tasdan (2009). While these studies have proved interesting findings, the question remains regarding the behavioral practices of organizational citizenship towards job satisfaction especially among special education teachers. In addition, it is also in line with the aims of the Ministry of Education Malaysia which places emphasis in the field of special education to improve achievements and changes in the national education ("More Special Education Teachers", 2018)

Therefore, the objectives of this study are:

1. to determine the organization citizenship behavior among Special Education Needs teachers.

2. to determine the levels of job satisfaction among Special Education Needs teachers.

3. to examine the relationship between organization citizenship behaviour and job satisfaction among Special Education Needs teachers.

\section{Organization Citizenship Behaviour}

Organ (1988) defined organization citizenship behaviour as work behavior that is discretionary, not directly or explicitly recognized by the formal reward system, and that, in the aggregate, promotes the effective functioning of the organization (Organ, 1988, p.4). 
Next, Organ (1997) explains that the performing of such actions must be without coercion and no punishment is imposed if it is not performed. Organ (1997) further added there is no guarantee that all organizational citizenship behavioral practices performed contribute to organizational success. Nevertheless, the effects of these practices generally contribute to positive outcomes. Organ (1997) has proposed five types of dimensions of organizational citizenship behavior namely (a) altruism or helpful behavior, (b) conscientiousness, (c) sportsmanship (d) courtesy and (e) civic purity.

Altruism is also known as helping or helpfulness (Organ, 1997). Volunteering to assist a new employee orientation, teaching staff useful knowledge or skills, and demonstrating employees how to complete difficult jobs are examples of altruism (1998: 87-98; Borman et al., 2001: 52-66).

Conscientiousness is the discretionary behavior that goes beyond the minimum role requirement set by the organization (Organ, 1988). These include arriving early at work, being punctual, obeying rules and regulations, not taking extra breaks and working extra-long days (MacKenzie et al., 1993; Organ, 1988; Shamsudin et al., 2020)

The sportsmanship dimension refers to the willingness of the employee to tolerate less than ideal circumstances without complaining (Organ, 1988). Complaining behavior is the opposite of the sportsmanship dimension. Individuals who show sportsman behaviour will not complain if things do not go well in the organization and take on a positive attitude (Muthuraman \& Al-Haziazi, 2017)

The Courtesy dimension is the discretionary behaviour aimed at preventing work-related problems with others from occurring (Organ, 1988). According to Podsakoff et al. (2000), employees who practise courtesy have less inter-group conflict and time to engage in conflict management activities.

The last dimension in organizational citizenship behavior is civic virtue. Civic virtue is a behavior on the part of an individual that indicates that the employee responsibly participates in, is involved in, or concerned about the life of the company (Podsakoff et al., 1990). This behaviour is demonstrated in being responsibly involved and supporting the strategies, showing the willingness to become committees or attending function organized by the organization (Sharma \& Jain, 2014).

Nasra and Heilbrunn (2015) defined teacher organizational citizenship behaviour as the willingness of teacher to carry out activities beyond their formal responsibilities with the goal of promoting the schools to achieve their goals. Various concepts have been studied about teachers and schools in the context of organizational citizenship behaviors such as teacher commitment (Bogler \& Somech, 2004), job satisfaction (Fatimah et al., 2011), the importance of organizational citizenship behaviors in the education context (Choong et al., 2016), servant leadership (Shamsuddin et al.., 2020), leadership style (Jameel et al., 2021).

In Malaysia, a previous study by Hairuddin (as mentioned in Ariffin, 2014) found that only $9.9 \%$ of teachers had organizational citizenship behavioral characteristics . A more recent study by Ibrahim et. al (2020) found the level of organizational citizenship behaviors among teachers was high.

\section{Job Satisfaction Among Teachers}

Several studies have been conducted to investigate job satisfaction among teachers. Job satisfaction among teachers is a vital indicator to provide a healthy environment for teachers and pupils (Nor et al., 2016). A study by Tugimin et al (2009) on job satisfaction among senior teacher found that demographic characteristics had a significant relationship with job 
satisfaction. Secondary school teachers in Bangsar (which is a zone in Kuala Lumpur, the capital of Malaysia) experienced moderate levels of job satisfaction (Hassan \& Abdul Wahab, 2017). The findings of this study are in line with the study of Hashim and Marappan (2011) which focused on job satisfaction among teachers In national type (Tamil) schools. The findings are also in line with the study results from Naseem (2005); Thurayya (2007) which showed that respondents' job satisfaction was at a moderate level.

A few job satisfaction studies involving special education teachers include the study by Mohamad and Yaacob (2013), where they found that there was no significant differences among special education teachers in primary and secondary schools based on remuneration factors, duties and work environment. Norazmi et al (2020) found that principal leadership $\&$ workload influenced special education teacher job satisfaction.

However, not many researchers have studied the association or relationship between organizational citizenship behavior and job satisfaction and almost no studies have focused on special education teachers. Fitrio et al (2019) studied the effect of job satisfaction on organizational citizenship behavior in Indonesia and found significant effect.

Based on the above discussion the following hypothesis proposed:

HO: There is no relationship between organization citizenship behaviour and job satisfaction among Special Education Needs teachers.

\section{Methodology}

A quantitative approach was used in this study. This paper presented the preliminary findings in which the respondents of the study consisted of 141 Special Education Integration Program teachers in secondary schools in the state of Perak, Malaysia. The item of the Organizational Citizenship Behavior questionnaire was adapted based on the study of Ibrahim et al (2018) who had adapted the questionnaire from instruments constructed by Podsakoff et al (1990). The Organizational Citizenship Behavior questionnaire contains 20 questions. The items in this section were measured using a Likert scale with a value of 1 to 7 ( $1=$ Strongly Disagree to 7 = Strongly Agree).

The items for job satisfaction were also adapted from Ibrahim et al (2018). The job satisfaction questionnaire also contained 20 questions. Responses in this section were measured using a Likert scale with a value of 1 to 7 ( $1=$ Strongly Disagree to $7=$ Strongly Agree). These researchers adapted a questionnaire developed by Weiss et al (1967) namely Minnesota Satisfaction Questionnaire (MSQ).

A pilot study involved 30 teachers in secondary schools which had conducted the Special Education Integration Program in one of the districts in Perak. Schools in this district were not selected in the actual study. The reliability test was conducted on the scale of measurement of Organizational Citizenship Behavior and Job Satisfaction using the Cronbach's Alpha test. The Cronbach's Alpha values for Organizational Citizenship Behavior and job satisfaction were 0.77 and 0.94 , respectively, which were higher than the values suggested by (Hair et al., 2010).

Descriptive statistics and correlation analyses were used to answer the objectives of the study. The following formula was used to determine the level of Organizational Citizenship Behavior and the level of Job Satisfaction:

Maximum value of scale (7) / number of levels (3). Therefore, the level class interval is 2.33. The interpretation of the mean score of the level of Organizational Citizenship Behavior and the level of Job Satisfaction is shown in Table 1. 
Table 1: Interpretation of mean score

\begin{tabular}{|l|l|}
\hline Mean score & Level \\
\hline $1.00-2.33$ & Low \\
\hline $2.34-4.66$ & Moderate \\
\hline $4.67-7.00$ & High \\
\hline
\end{tabular}

To determine the strength of the relationship, the guidelines by Pallant (2020) were used as follows:

Table 2: Interpretation of Pearson Correlation

\begin{tabular}{|l|l|}
\hline Correlation coefficient $(\mathbf{r})$ & Strength \\
\hline $0.10-0.29$ & Low \\
\hline $0.30-0.49$ & Moderate \\
\hline $0.50-1.0$ & High \\
\hline
\end{tabular}

The profile of the respondents is presented in Table 3. The sample is dominantly female (86\%), Malay ethnic (77\%) and age $31-40$ years old (54\%). Majority of the respondents (82\%) had bachelor degrees and most of them had teaching experience between 1-10 years (36) and $11-20$ years $(44 \%)$.

Table 3: Respondents Profile

\begin{tabular}{|c|c|c|c|}
\hline \multicolumn{2}{|c|}{ Demographic Profile } & Frequency & Percent \\
\hline \multirow[t]{2}{*}{ Gender } & Male & 20 & 14.2 \\
\hline & Female & 121 & 85.8 \\
\hline \multirow[t]{4}{*}{ Age } & $21-30$ years old & 14 & 9.9 \\
\hline & $31-40$ years old & 76 & 53.9 \\
\hline & $41-50$ years old & 40 & 28.4 \\
\hline & $51-60$ years old & 11 & 7.8 \\
\hline \multirow[t]{4}{*}{ Ethnic } & Malay & 108 & 76.6 \\
\hline & Chinese & 5 & 3.5 \\
\hline & Indian & 27 & 19.1 \\
\hline & Sikh & 1 & 0.7 \\
\hline \multirow[t]{4}{*}{ Education profile } & Diploma & 5 & 3.5 \\
\hline & Bachelor degree & 116 & 82.3 \\
\hline & Masters & 19 & 13.5 \\
\hline & PhD & 1 & 0.7 \\
\hline \multirow[t]{4}{*}{ Years of service } & $1-10$ years & 50 & 35.5 \\
\hline & $11-20$ years & 62 & 43.9 \\
\hline & $21-30$ years & 23 & 16.3 \\
\hline & 31 years and above & 5 & 3.6 \\
\hline
\end{tabular}

\section{Findings of the Study}

The first and second objectives were to determine the level of Organizational Citizenship Behavior and Job Satisfaction among special education teachers. The levels were determined by the mean of each variables. The results on Table 4 show the level of Organizational Citizenship Behavior and Job Satisfaction were high with mean scores of 6.024 and 5.652 respectively.

Table 4: Total mean scores for Organizational Citizenship Behavior and Job Satisfaction 


\begin{tabular}{|l|l|l|l|}
\hline & Mean & $\begin{array}{l}\text { Standard } \\
\text { Deviation }\end{array}$ & Levels \\
\hline Organizational Citizenship Behavior & 6.024 & 0.560 & High \\
\hline Job satisfaction & 5.652 & 0.785 & High \\
\hline
\end{tabular}

The relationship between Organizational Citizenship Behavior and Job Satisfaction was investigated using Pearson correlation. Preliminary analyses were performed to ensure no violation of assumptions. The result summarized in Table 5 clearly indicated that there was a positive relationship between Organizational Citizenship Behavior and Job Satisfaction, $r=$ $0.533, \mathrm{n}=141, \mathrm{p}<.0005$.

Table 5: Pearson Correlation test on the relationship between Organizational Citizenship Behavior and Job Satisfaction

\begin{tabular}{|l|l|l|l|}
\hline \multirow{2}{*}{$\begin{array}{l}\text { Organizational } \\
\text { Citizenship Behavior }\end{array}$} & $\begin{array}{l}\text { Organizational } \\
\text { Citizenship Behavior }\end{array}$ & Job satisfaction \\
\cline { 2 - 4 } & Pearson Correlation & 1 & $0.533^{* *}$ \\
\cline { 2 - 4 } & Sig (2 tailed) & & .000 \\
\cline { 2 - 4 } Job satisfaction & Pearson Correlation & $0.533^{* *}$ & 141 \\
\cline { 2 - 4 } & Sig (2 tailed) & .000 & 1 \\
\cline { 2 - 4 } & $\mathrm{N}$ & 141 & 141 \\
\hline
\end{tabular}

** Correlation is significant at the 0.01 level ( 2 tailed)

\section{Discussions and Conclusion}

The purpose of this paper was to investigate the level of Organizational Citizenship Behavior and Job Satisfaction, as well as to investigate the relationship between Organizational Citizenship Behavior and Job Satisfaction. The descriptive results in this study showed that both the level of Organizational Citizenship Behavior and Job Satisfaction were high. The finding on Organizational Citizenship Behavior supports earlier study by Amira et al (2020). However, the finding for job satisfaction was not in agreement with Hassan and Abdul Wahab (2017); Hashim and Marappan (2011); Naseem (2005); Thurayya (2007), which showed that respondents' job satisfaction was at a moderate level. The finding also showed a positive relationship between Organizational Citizenship Behavior and Job Satisfaction which indicated a good sign.

This paper only reported preliminary finding as such, the results cannot be projected onto the population as a whole. However, the results can give some insights in increasing our understanding regarding Organizational Citizenship Behavior and Job Satisfaction among special education teachers.

In short, this study is important for schools to benchmark job satisfaction of special education teachers. It is also important to the State Education Department as an input so that appropriate action can be taken. It is hoped that the stated parties will strive to improve the planning for special education students and teachers.

Organizational citizenship behavior should be seen as one of the factors that can increase the effectiveness of an organization, especially school organizations. This is because the teaching profession and especially special education teachers need individuals who are willing to contribute energy and time to work beyond their official duties to help these special students. 


\section{References}

Amira, I., Fatimah, WATI, H., Shahrazad, W. S., \& Ariff, M. I. (2020), The role of organizational citizenship behavior as a mediator in the effect of work passion factors on organizational commitment among teachers in Selangor. International Journal of Psychosocial Rehabilitation, 24 (4), 4268-4287.

Ariffin, J. B. (2014). Keadilan organisasi, tingkah laku kewarganegaraan organisasi dan kepercayaan di sekolah rendah utara Semenanjung Malaysia (Unpublished Doctoral thesis). Universiti Sains Malaysia.

Choong, Y. O., Yunus, J., \& Yusof, J. (2016), The importance of organizational citizenship behaviour in Malaysia Education, International Journal of Academic Research in Business and Social Sciences, 6 (11), 740-746.

Fatimah, O., Amiraa, A. M., \& Halim, F. W. (2011). The relationship between organizational justice, organizational citizenship behavior and job Satisfaction. Pertanika Journal of Social Sciences \& Humanities, 19, 115-121.

Fitrio, T., Apriansyah, R., Utami, S., \& Yaspita, H. (2019). The effect of job satisfaction to organizational citizenship behavior (OCB) mediated by organizational commitment. International Journal of Scientific Research and Management, 7(09), 1300-1310.

Hair, J. F., William C. B., Barry J. B., Rolph E. A., \& Tatham, R. L. (2010). Multivariate data analysis: A global perspective (7th Eds.). New York Person Education Inc.

Hashim, S., \& Marappan, S. V. (2011). Kepuasan kerja dalam kalangan guru di sekolah-sekolah jenis kebangsaan (Tamil), daerah Kulai. Journal Pendidikan. Universiti Teknologi Malaysia (Unpublished).

Hassan, J., \& Abdul Wahab, J. (2017), kepuasan kerja dalam kalangan guru di sekolah menengah zon Bangsar, Seminar Serantau 2017, Universiti Kebangsaan Malaysia. Retrieved from https://seminarserantau2017.files.wordpress.com/2017/09/48norhazwani-hassan.pdf

Ibrahim, M. A., Wan Sulaiman, W. S., \& Hafidz, M. S. W. (2018). Tingkah laku kewargaan organisasi sebagai mediator dalam hubungan di antara kepuasan kerja dan komitmen organisasi terhadap prestasi tugas dalam kalangan pensyarah universiti. Sains Humanika, 10(3), 47-56. https://doi.org/10.11113/sh.v10n3.730

Jameel, A. S., Hamdi, S. S., \& Massoudi, A. H. (2021). The role of transformational and transactional leadership as predictors of organizational citizenship behavior in education system. Cihan University-Erbil Journal of Humanities and Social Sciences, 5(1), 56-62.

KPM akan tambah guru Pendidikan Khas (2019). Sinar Harian https://www.sinarharian.com.my/article/7856/BERITA/Nasional/KPM-akan-tambahguru-pendidikan-khas

MacKenzie, S. B., Podsakoff, P. M., \& Fetter, R. (1993). The impact of organizational citizenship behavior on evaluations of salesperson performance. Journal of Marketing, 57(1), 7080.

Mohamad, J., \& Yaacob, N. R. N. (2013). Kajian tentang kepuasan bekerja dalam kalangan guru-guru pendidikan khas (a study on job satisfaction among special Education teachers). Asia Pacific Journal of Educators and Education, 28, 103-115.

Norazmi, M. N., Zaid, M., \& Abdul Rasid, A. R. (2020). Relationship between headmasters' leadership, task load on Special Education Integration Programme teachers' job 
satisfaction. Universal Journal of Educational Research, 8(8), 3398 - 3405. DOI: 10.13189/ujer.2020.080813

More special education teachers needed (2018). New Straits Times. https://www.nst.com.my/news/nation/2018/07/387900/more-special-educationteachers-needed

Muthuraman, S., \& Al-Haziazi, M. (2017). Examining the factors of organizational citizenship behaviour with reference to corporate sectors in Sultanate of Oman. International Review of Management and Marketing, 7(1), 413-422.

Naseem, K. (2005). Hubungan burnout dan kepuasan kerja: Tinjauan di kalangan kaunselor sekolah menengah di daerah Johor Bahru (Unpublished Master's thesis). Universiti Teknologi Malaysia.

Nasra, M. A., \& Heilbrunn, S. (2016). Transformational leadership and organizational citizenship behavior in the Arab educational system in Israel: The impact of trust and job satisfaction. Educational Management Administration \& Leadership, 44(3), 380396.

Nor, M. Z. I., Jamalul Lail, A. W., Ruzita, M. H., (2016). Kepuasan kerja guru dan perbezaannya berdasarkan pencapaian sekolah. Jurnal Personalia Pelajar, 19 (1), 49-54.

Oplatka, I. (2009). Organizational citizenship behavior in teaching: The consequences for teachers, pupils, and the school. International Journal of Educational Management, 23 (5), 375-389.

Organ, D. W. (1988). Organizational citizenship behavior: The good soldier syndrome. Lexington Books/DC Heath and Com.

Organ, D. W. (1997). Organizational citizenship behavior: It's construct clean-up time. Human Performance, 10(2), 85-97.

Podsakoff, P. M., MacKenzie, S. B., Moorman, R. H., \& Fetter, R. (1990). Transformational leader behaviors and their effects on followers' trust in leader, satisfaction, and organizational citizenship behaviors. The Leadership Quarterly, 1(2), 107-142.

Podsakoff, P. M., Mackenzie, S. B., Paine, J. B., Bachrach, D. G. (2000). Organizational citizenship behaviors: $A$ critical review of the theoretical and empirical literature and suggestions for future research. Journal of Management, 26(3): 513-563.

Raso, R. (2014). Stres Dan Kepuasan Kerja Guru Pendidikan Khas Di Daerah Johor Bahru (Unpublished Master's thesis). Universiti Teknologi Malaysia.

Shamsuddin, S. H., Mohamad, S. I. S., \& Hashim, Z. (2020). Relationship of Servant Leadership Towards Organizational Citizenship Behaviour (OCB) and Job Satisfaction Among Teachers: A Review of Literature. International Journal of Politics, Publics Policy and Social Works, 2 (7), 79-92.

Sharma, V., \& Jain, S. (2014). A scale for measuring organizational citizenship behavior in manufacturing sector. Pacific Business Review International, 6(8), 57-62.

Strydom, L., Nortjé, N., Beukes, R., Esterhuyse, K., \& van der Westhuizen, J. (2012). Job satisfaction amongst teachers at special needs schools. South African Journal of Education, 32(3), 267-278.

Thurayya, O. (2007). Hubungan burnout dengan kepuasan kerja di kalangan staf Jabatan Agama Johor. (Unpublished Master's thesis). Universiti Teknologi Malaysia.

Tugimin, A. J., Saadan, R., Yusof, M. N., \& Hasan, H. (2009). Perkaitan persepsi terhadap organisasi dengan kepuasan kerja dalam kalangan Guru Penolong Kanan Sekolah Menengah Negeri Melaka. Journal of Human Capital Development, 2(1), 65-75. 
Weiss, D. J., Davis, R. V., England, G. W., \& Lofquist, L. H. (1967). Manual for the Minnesota Satisfaction Questionnaire. The University of Minnesota Press, Minneapolis.

Yavuz, M. (2018). Examination of the job satisfaction of teachers working with individuals in need of special education with regard to certain variables. Journal of Education and Training Studies, 6(7), 73-85.

Yilmaz, K., \& Taşdan, M. (2009). Organizational citizenship and organizational justice in Turkish primary schools. Journal of Educational Administration, 47(1), 108-126. 